\title{
HARMONISATION OF THE VILNIUS URBAN DEVELOPMENT: PROBLEMS AND TRENDS OF ACTIONS
}

\author{
Pranciškus Juškevičius \\ Departament of Urban Engineering, Vilnius Gediminas Technical University (VGTU), \\ Sauletekio al. 11, LT-2040 Vilnius, Lithuania
}

Received: 27 December, 2002

\begin{abstract}
The article provides the analysis of the evolution of the planning principals and physical development of the City since 1988 when the state determined planning was mandatory, covering the period since the adoption of the Law on Territorial Planning up to the present date when the City operates in the market economy conditions. The controversy of the City planning and development is pointed out, as well as the necessity to liberalise and harmonise the process.
\end{abstract}

Keywords: principals of urban planning. Determined planning, Comprehensive Plan, Strategic Plan, market economy, land use management, conversion, monitoring.

\section{Preface}

The Lithuanian urban development was strictly regulated almost 50 years. Every town and settlement as well as some villages had their general (master) plans. The turning-point in the legal sense took place in 1995 when Seimas has passed a Law on Territorial Planning for the first time.

Since enforcement of the Law on Territorial Planning same important momentum became highlighted:

At first, there were prepared very few comprehensive plans - for Vilnius and Klaipeda only. Other towns and settlements were not interested in preparation of them due to stagnancy or slight development and absence of needs or various subjective causes.

Secondly, in Vilnius and other cities there were established municipality owned urban planning enterprises as "Vilniaus planas", "Kauno planas", etc., in order to collect information, planning management and operative planning secure. That was positive and inescapable process. At the same time it should be conceded that their activity has assumed same monopolistic features.
Thirdly, exertions to protect local planners by ignoring their real competence emerged through all Lithuania. Poor normative planning basis, no new methodology publications and very little planning market imply to possibility of not high planners qualification. This is a hypothesis because qualifications of the planners arc not identified due to absence of qualification assessment system.

Fourthly, a gap between stable provisions of the Law on Territorial Planning and possibilities for realisation of these provisions is speeding up due to deepening of the market economy relations.

Fifth, more and more often the permanent work of the planners-analysts - analysis of the urban development, alternative development, substantiation - is being changed by political authority's decisions, and the strategic planning partly replaces the territorial planning. Therefore there appears a "white spot" - an unspecified urban physical structure development. This indeterminacy is being accompanied by many negative consequences.

The situation of Vilnius in this context is extraordinary. 
The Vilnius urban planning works as a whole formally conforms to all essential requirements of the territorial planning: the comprehensive city plan is approved, detailed plans and special plans are under preparation and approval, the operative planning process is going on. Besides that, the strategic urban development plan is prepared and approved as well.

Thus, by the Vilnius urban model it is convenient to explain common and specific planning problems and their reasons and outcomes. That is a goal of the article.

\section{Operative planning works and comprehensive plan subject}

The main operative planning works at the "Vilniaus planas" are associated with the existing street network review and search for the new decisions that would be able to reduce urban transportation problems (fig $1)$ :

- Alternative link of the western high speed street with the Oslo street;

- Efficient crossing type for Ukmergès - Geležinio vilko - Žalgirio streets (traffic schemes);

- New street route in the existing Lvovo and Krokuvos street area as well as adequate place of them in the street framework;

- The new bridge adequate route from the J. Tumo - Vaižganto street prolongation to Ukmergès and Žalgirio street;

- Traffic possibilities of the Zarasu street link with Paneriu street and partly functional alternative to P. Višinskio and Sukilèlių street framework;

- Duplicating routes for the high-speed traffic along the Oslo street and Laisvès Ave (Lazdynu bridge).

Strictly talking, the majority of the planning subjects are not newly identified. For some of them importance was proved more than ten years ago in the former Vilnius urban Master plan. Therefore, a statement is possible, as follows:

- Implementation of the transport system's objects has been too long and the implementation mechanism is inefficient.

- The changed social, economic conditions, different way of life and level of the citizen incomes, as well as their differentiation and even essential changes of the urban functional structure did not change the way of traffic flows formation. Therefore, an affirmation is possible on causes for transportation being set in the physical structure of the street network.

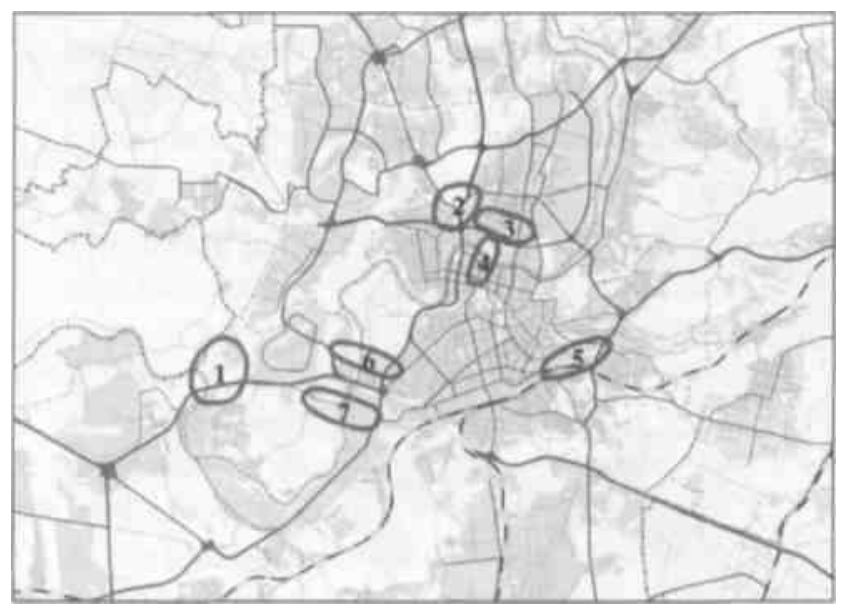

Fig 1. Street network foreseen in the Comprehensive Plan of Vilnius and operative planning works by Vilniaus Planas in 2002

The presented list indicates that from the planning hierarchy point of view, all works are a subject of the general planning and there is an attempt by the entire works to resolve the principal tasks of the street network formation in the Vilnius central part $\bullet$

However, the context of these tasks decision should

be more wide - not only the central part and not a whole city. A mature necessity emerged to overpass to the other planning subject. The administrative urban borders, basically, are voluntaristic. The influence of Vilnius surrounding territories determined active suburbanisation and rural-urbanisation processes. Therefore, Vilnius de facto is much bigger than its administrative territory. Practically, an urban region has formed itself (Fig 2). Really, for determining its borders should be an agreement made relating criteria, their number and quantity or quality values.

However, as praxis show, the municipalities undergo troubles seeking common planning. Besides that, the legal basis is not favourable.

The Vilnius urban region is being formed by the intensive centripetal links. These links are everyday's travels by car from urban peripheral part and outskirts to Vilnius for a work and other personal, children or all family interests. The centripetal links will become stronger due to a minimal labour and services supply in all mentioned territories, meanwhile, during the last 10-15 years there appeared a possibility for singlefamily houses construction. The development possibilities are not exhausted meanwhile, and the public transport is not competitive to car transport.

The links will grow even thereupon establishing of so called second houses by Vilnius citizens. 


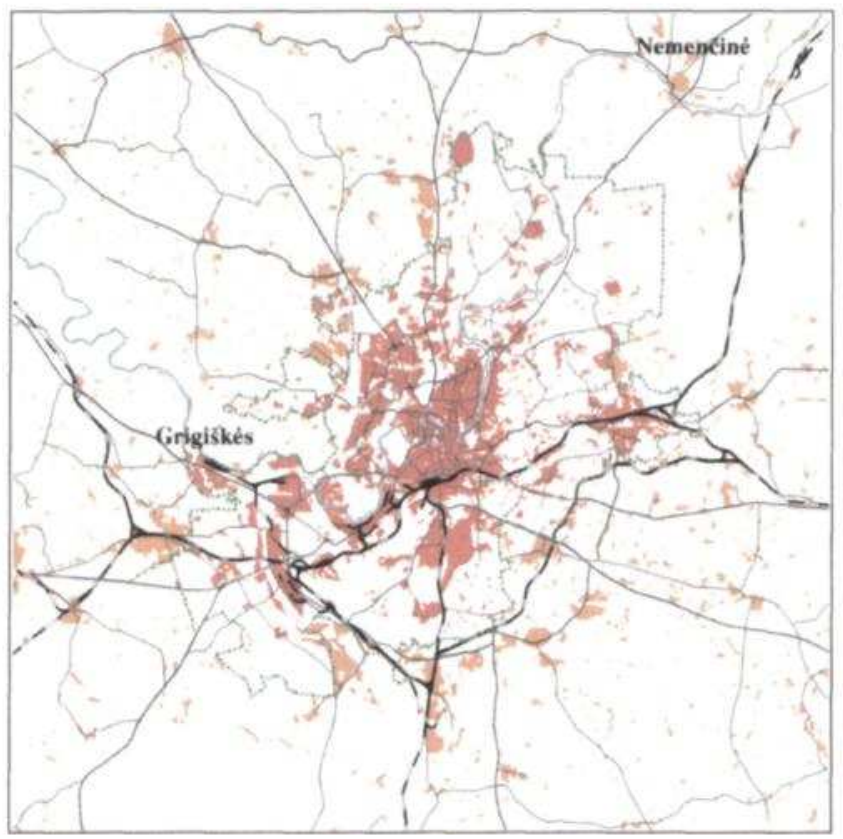

Fig 2. A field within Vilnius City

The radial streets and roads towards Molètai, Utena, Ukmergè, Kaunas, Trakai and other directions are axis of the Vilnius urban region sectors, where concentrated flow encompasses the urban centre. A reliability of such system is low, meanwhile, vehicle flow permeability is limited (Fig 3). Therefore, the works carried out in "Vilniaus planas" should be connected by one idea - perfection of the Vilnius street network by assessing city centre, all city and Vilnius urban regional development interests and traffic dynamics. This idea should stimulate arrival of another idea, the concept of Vilnius urban region structure.

The typical examples of such integrated planning subjects in the latter time period were metropolitan planning of Berlin and Brandenburg land region [1], planning of Stockholm development [2].

An inception of such planning already was in 19941996, when the concept of Vilnius and its region perspective development was formulated and announced in the second vision of the Vilnius urban development up to 2015 [3]. However, there were no further steps made.

By planning the Vilnius region but not Vilnius itself, there is necessary agreement with the neighbour municipalities, especially Vilnius and Trakai municipalities. Author of the article has no information, whether there were any attempts of negotiations and if no agreement was made - what kind of reasons were tackled. It is possible only to state that late in 1998 approved by the Vilnius city Council the Vilnius urban Comprehensive plan covers only administrative terri-

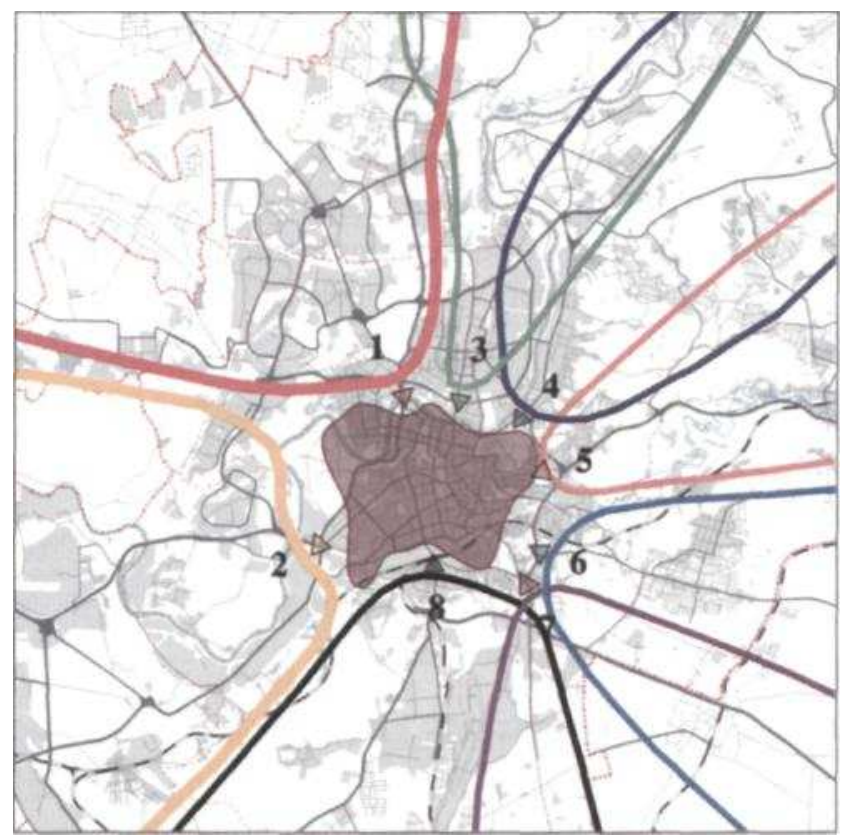

Fig 3. Sectors of Vilnius City served by radial streets (main roads)

tory, meanwhile, its external structure was identified with the green ring tasks in outskirts, where solution has been related with the mentioned agreement and need for changes of the administrative boarders [4].

Municipality agreements on the common actions in territory planning, technical infrastructure and similar areas are not frequent. According to authors of the Gdynia strategic plan, co-operation between neighbouring municipalities even from the same agglomeration is poor; actually favourable efficiency of integrated structures is not a weighty argument [5]. However, there are solid examples of common development planning even in the international extent, for instance, between Viena and Bratislava [6, 7].

The problem could and should be solved thanks to new provisions of the Law on Territorial Planning, that could create a possibility to plan de facto opened city, but not only city within administrative borders.

It seems, that other alternatives even in short time period are not real.

\section{Vilnius urban planning developments}

During the last 15-20 years the principles of the urban planning and management have changed. Last year history of the Vilnius Comprehensive Plan preparation quite well reflects phases of the changes: • Until 1988 the state planning initiated by the state authority predominated and decisions of the planning were addressed to the same state authority institutions. The main features of the planning 
were secret and determined process with strict control of decision implementation, review of decisions was sparse - every 10 years or like, free disposition of the state land.

- In 1988-1989 the wide development program for the Vilnius Execution Committee was under preparation by experts from various institutions. In sense of ideas (or goals) it was similar to the strategic planning which is modern in nowadays. The undertaking was not realised, however, some versions have been prepared [8]. These plans clearly demonstrate a certain nonplus of planners in vague and hard predictive social and economic area and a partly voluntaristic interpretation of the area.

- In 1994 organised contest for urban development plan preparation ended with declaration of two development (more physical area) versions as the first and second visions of the Vilnius urban development until 2015 [3].

- In 1995-1996 these visions and other ideas have formulated essential solutions that were approved later. It is difficult to predict emphatically and to argument that the comprehensive plan has reflected the market economy essence and spirit. Although there arc no arguments denying that there were no elements inherent the planning in the market economy conditions neither. The operative (permanent) planning could be as the clement. It seemed that this innovation will serve as good instrument for monitoring, analyse operative reaction into dynamic urban development processes. However, the expectations did not stand up.

- Until 2002 the planners step by step have acquired the planning experience partly meeting the market relations level, and private structures gained enough high rank for questioning and making influence to the comprehensive plan solutions.

The private structures and persons very soon will take over initiative for urban development. Currently they determine the housing type, volumes and localisation in the city or outskirts; they decide on the construction of the new large and small trading service centres and on reconstruction of present ones. This may be said to be a normal process. However, not always the activity meets interests of the city community. Even more, they are not able to meet principles of the sustainable development $[6,9]$.

One of the principles of sustainable development is a necessity of short trips city. Vilnius never could be characterised by this attribute [6]. Meanwhile, recently established system of hypcr-largc trading, recreational and service centres has outrivaled network of small shops and service enterprises, and this stimulated cartrips, concentrated their flows and made the trips longer.

The other principle is functional integration and structurisation of residential areas. This factor reduces need of communication with transportation means, stimulates creation of informal neighbourhoods and adequate maintenance of territories It is complicated to find such examples in residential areas built in 1970-1990. Current development is inherent with mono-functional, small and dissipated in the urban periphery and outskirts a new small housing estates as well as groups of houses without any social and other infrastructure, without public space, land reserves for mentioned and other needs. Residents are dependent on car and this forms the long trip flows concentrated in space and times.

The third important principle is a compact city with public transportation. Vilnius is not compact, excluding its central part. In the peripheral part there is disperse and chaotic repartition of small residential complexes. Therefore, there is inefficient land-use, deep problems for creation and retention of technical infrastructure and public transport system.

The forth principle is intensive built-up of areas. That is the necessary environment for the viable public transportation system, economic land-use and efficient functioning of engineering systems. Vilnius inherited the intensive built up environment since previous time. The mass housing construction started in 1960-1965, and it conformed to all requirements mentioned above. They arc identical for understanding of the sustainable development.

However, the real processes of the latter decade in Vilnius are contradictory - unsustainable low-rise construction and additional construction in already existing built up areas. This additional construction is being understood from the viewpoint of financing and economic benefit. However, in others - transportation, healthy residential environment, psychological climate, etc. - are not acceptable or in the best case, can be under consideration in the concrete situation and in concrete environment.

Earlier presented arguments allow to state, that the comprehensive urban plan, reflecting common urban inhabitants' interests, the principles of sustainable urban development de facto are recommendations.

The comprehensive plan could be as such in case if its recommendations would be based on the benefits of the plan realisation and land-use management would be not so weak. 
The worse feature of the management - inability to sustain status quo there, where is a need (i.e. reservation of land lots for the public space), and otherwhere visa versa - to transform lots boarders for structurisation of large land lots, meanwhile, later for planning and reclamation under normal management. At the moment the main problem is the structurisation of new large land lots. The long-drown solution of the problem is an obstacle for the smooth development.

While expanding idea of the comprehensive planning development a question arise: what is the subject for the comprehensive planning?

There were no doubts theoretically and practically on the technical infrastructure importance to the city functioning and development. Therefore, the urban street network may serve as a background for co-ordination of private and common urban interests due to the transportation system secures implementation of all interests.

Thus are proposed and shall be discussed two principal provisions of the comprehensive planning:

- The street network (total urban technical infra structure) should remain as a subject for compre hensive planning. Solutions of the comprehensive plan should be kept as mandatory. Therefore, a duty of the urban authority - to develop the street network and secure it from attempt to make disbalanse due to conjuncture and local interests.

- Solutions for all other possible planning objects (except protected and similar territories) should be considered as recommendations. The real so lution may be achieved by negotiations. Here municipalities, community representatives and private structures should participate in one or other form.

\section{Priorities of the Vilnius development}

In the strategic plan Vilnius 2002 for urban transportation, and more precise - for transportation development, one of the first priorities is devoted in all queue of priorities for urban system development.

Practically this is one more, at the moment already political endorsement of solutions in the comprehensive plan.

According to the authors' opinion there is a need to make more precise objectives of the urban transportation system development for items formulated in the Vilnius strategic plan [10]:

- geopolitical objectives of the Vilnius develop ment,
- modernisation of economics,

- objectives for declaration of opened city, etc.

The specification is being stipulated due to pragmatic reasons:

- The existing Vilnius street network is very little differentiated following the technical level (categories), therefore, there is absence of rational traffic distribution according to speed, short and long links, real and local transit and local traffic, etc.

- Coherence of the existing network is low therefore it is not reliable and this is determined by so called critical crossings, street sections, lack of bridges, overpasses, not finished streets and overpasses.

- Working nature of bus, trolley-bus paths are traditionally monotonic, without any specific integration with other transportation patterns - walking, bikes and cars. All types of public passenger transportation provide essentially services of the same low quality level and are not able to compete with cars.

- Motoring level is continually growing (at the moment it amounts 350 cars/1000 inhabitants). Due to absence of alternative for cars, role of the public transportation falls down up to $30 \%$ (by calculating passenger kilometres in transition). In the new development territories (peripheral urban and outskirts areas) their dominance is absolute.

- The way of life changes. Part of presumptions and reasons: cars, large and very large trading centres, low-rise building, development of residential area of Vilnius citizen, reducing and somewhere groundless growing density of built up territory.

These arguments mentioned above make us to think that to Vilnius - capital and metropolitan, having big development potential and clearly expressed ambitions - it is necessary essential modernisation of the Vilnius urban region transport system.

\section{Modernisation objectives}

1. Creation of integrated network of high-speed streets and highways outside a city. While creation there should be evaluated:

- Existing and forecasted territorial development as well as the great Vilnius (Vilnius urban region) with functionally integrated settlements, summer resorts and recreational territories.

- Indctermination of the urban development in time and space. The indetermination in the functional and development speed point of view force to 
think on conditionally universal network or otherwise - network, which could secure normal urban functioning, essentially independent from the links as whole changes. Thus would be created a balance to the urban development indetermination.

- The attribute of high-speed traffic streets (or highways) to change attractiveness of the neighbouring territories to investment, to change landuse character and to regulate the urban development.

- Need to increase reliability of the street network. Actually, it would mean increase of coherence of the existing network.

- Concentration of the high-speed and intensive car transportation in the streets. It could improve situation in the rest street network: decrease of direct noise level, exhaust gas impact to citizen, conflict between pedestrian and transport means, improvement of public passenger transport working conditions.

- Interests of urban centre and old town: it is necessary to minimise transit flows, beforehand distribution of incoming flows (i.e. decrease of dispensation in the network of the central inner streets). Need to increase representative and elementary urban possibilities to receive official guests, tourists as well as everyday city visitors.

The principal network of the high-speed streets and outside urban highways network, integrated with the streets of lower category is presented on Fig.4. This proposal is minimalist and should be developed further - in the Vilnius urban region.

\section{Creation of subsystem of the high-speed passengers transportation.}

The idea of high-speed transportation is not new.

Two decades ago an efficiency of high-speed bus lines, functioning in the central isolated street belt was investigated. This subsystem appeared not efficient and it was outrivaled by tram.

Idea of the high-speed tram and its substantiation works were carried out in 1986 - 1988 (The Vilnius General plan, MSPI), 1994-1996 II version of the Comprehensive plan, 2002 - SYSTRA and proposals of the "Vilniaus Planas".

The mentioned proposals are similar:

- tram network should be created for improvement of links between Lazdynai, Karoliniškès and other residential estates with urban centre, old town, railway station and airport;

- actually, the network is being created along the same streets, that at the moment are mostly

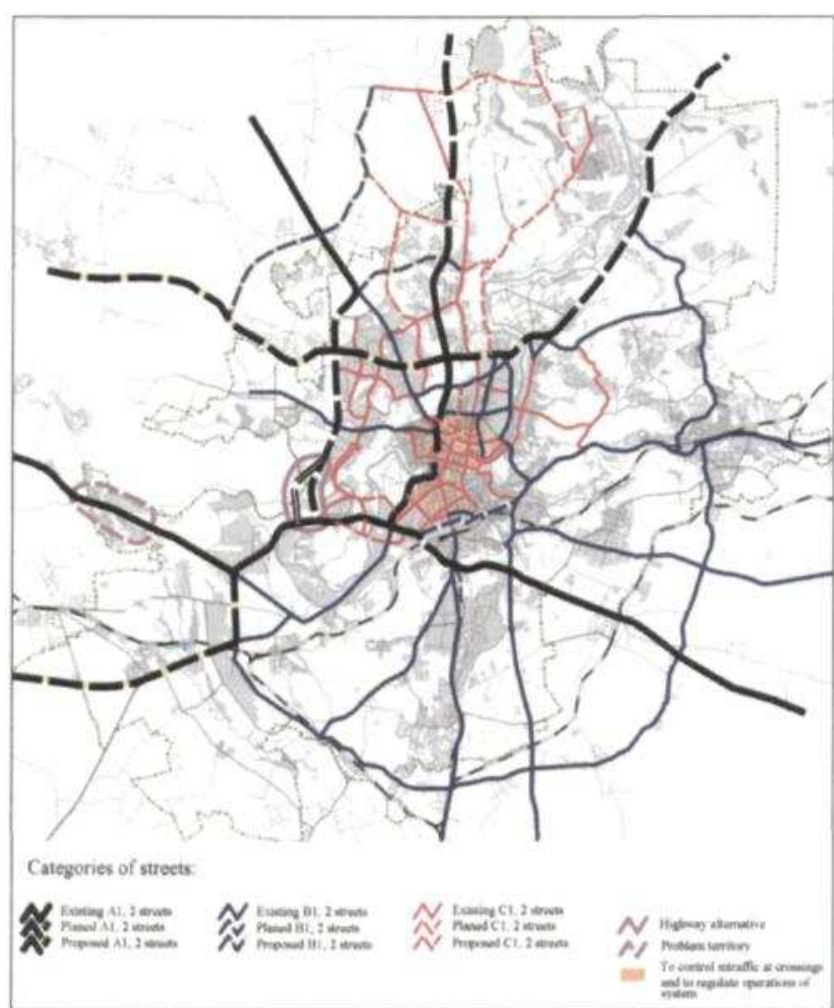

Fig 4. Proposed street network

loaded and where trolley-bus lines are functioning;

- To provide new quality to the public transporta tion system and to stabilise its role.

However, functioning conditions of the tramlines and environment (theoretical and practical) have changed: increased motoring level, high street network loading with flows level, property differentiation of citizens, and competitiveness in the passenger transportation market. Possibilities of investment for creation of such system have changed as well.

It is predicated that trams proposed by SYSTRA and "Vilniaus planas" are modern, convenient, nice and efficient. However, it is not the tram, which system would be able essentially to extend possibility to choice the public transportation ways according to speed up to $30-35 \mathrm{~km} / \mathrm{h}$.

A priori is possible to state that in the real sense of future:

- Density of tramlines will not be high and it will not repeat all the existing buses and trolley-buses network.

- There is a big probability that the first and for some time period a single tramline will not make a revolution in the passenger transportation market. There is small chance that functioning of the 
line will encourage the bigger number of citizen to refuse a car. The category of inhabitants could be replenished by people whose work and live (or service) locations are within the tram service area and whose trips are not related to transportation of members of family to work, school, etc. outside of the area.

- The highest efficiency of tram is expected only in the integrated urban system, comprised of pe destrians, bikers, buses and trolley buses traffic.

Therefore, creation of the tram subsystem should evaluate:

- Particular substantiation of the first one or two line routes - not only functional, technical, social, structural role (probability of land and buildings purpose);

- Changes of traffic and building service conditions in streets, where tram lines would be introduced as well as in neighbouring streets and crossings;

- Reconstruction of the existing passenger transportation system in order to look for the best integration pattern;

- Large initial capital investment and uncertain incomes and as a subsequent - high subsidies for the tram subsystem support. Growing car use and decreasing of financial ability of passengers to be transported by the public transport determine the uncertain incomes.

Proposed two tramlines and trolley-bus network are presented on Fig 5.

3. Implementation of computerised systems for traffic in crossing management, regulation and information.

Vilnius in this area has nothing to boast about. All being used stoplight regulation systems essentially are hard, uncoordinated and mainly out of date morally and physically.

The computerised systems at first should be installed in the urban centre. They could allow:

- Increase of conductance in crossings without essential reconstruction of streets and crossings itself;

- Better use of the existing street network;

- Evaluate interests of pedestrians;

- Grant at least partly traffic priority in crossings for the public transport;

- Essential improvement of the provision of information on the traffic regulation.

- Operative change of the traffic regime according to demand (regime in weekend and holidays, traffic regime during visits of officials and city guests, etc.).

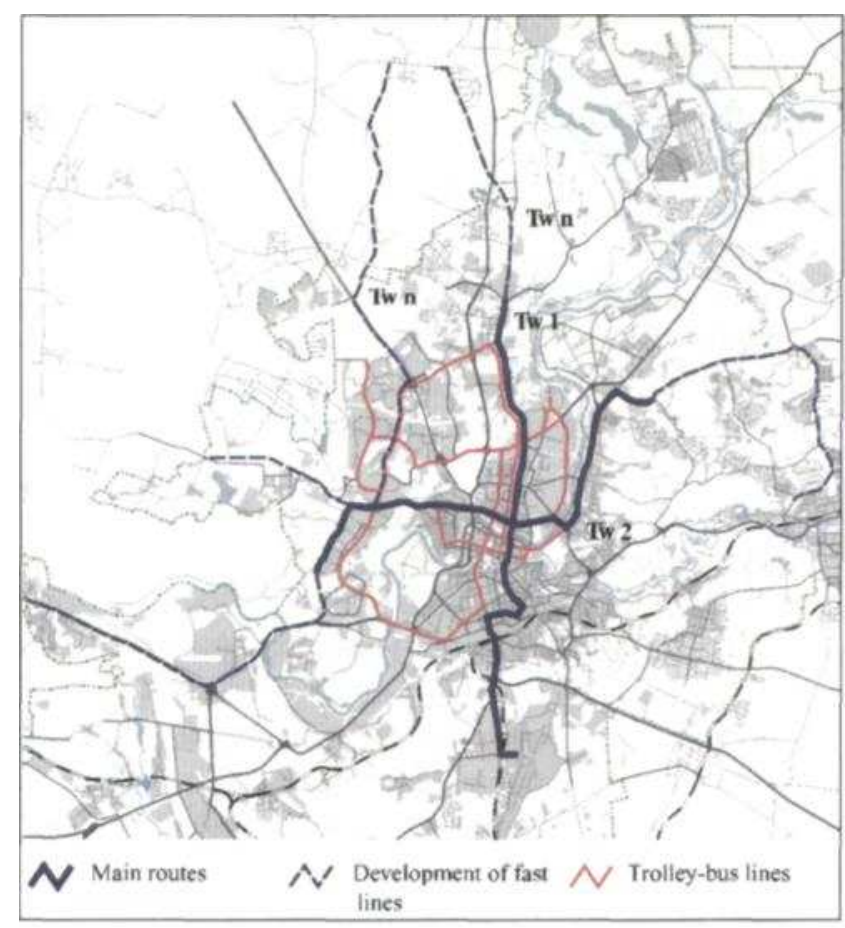

Fig 5. Proposed network of tram and trolley-bus lines

\section{Conclusion}

The last 15 -year period was marked by attempts to find effective Vilnius urban planning model in the market economy conditions. The current situation is contradictory: planners have acquired the experience, which partly conforms the achieved market relations level, however, the real urban development initiative is being intercepted by private structures meanwhile, subsequences of the initiative are controversial.

The contradiction of the urban planning and development is determined by

- Weak management of land-use, unsuited for urbanised territories;

- Inefficient mechanism of co-ordination of objective general urban interests and private interests, as well as of planning solutions implementation.

- Complicated planning procedures, groundless universal obligation of planning solutions; to many details in the comprehensive plan, without association with the strategic planning objectives; scarce validity of the planning solutions and links with the investment processes.

Every new building - industrial, trading, service or for other purpose, new residential estate changes a transportation need and make influence to choice a transportation way, meanwhile, every new bridge, street changes transportation conditions and problems. 
Therefore, a monitoring system should act for the city, urban region development and transportation system functioning and their outcomes. It is a basis for actions in urban evaluation and operative (permanent) planning.

Particular attention shall be devoted to the North South corridor alongside the high-speed traffic in Geležinio Vilko Street. Here falls urban centre, old town, complexes of higher and other schools, specialised medical and scientific centres, trading and service centres, churches, recreational and sport territories, existing residential estates, railway station, airport. The corridor will be complemented by new centre, being planned sport and service centre, forecasted to be conversion territories (Fig 6). Here, along the corridor the urban functional axis is under formation. This may be the essential change of the Vilnius urban physical and functional structure. It should be supported by extend of the transportation system capacity.

\section{Proposals:}

1. All at present carried out operative planning works shall be systematically joined into the transportation system development plan of the Vilnius urban region.

2. Vilnius urban region should be the planning subject. Therefore, the agreement among the neighbouring municipalities is necessary. The administrative borders should stay without changes.

3. Transportation system development objectives, already formulated in comprehensive and strategic plans, shall be specified and complemented with such formulation: modernisation of the Vilnius urban region transportation system.

4. The focus of modernisation: high-speed traffic street network, computerised system of highspeed passenger transportation subsystems for management of the urban centre traffic in crossings.

5. The high-speed street network, already planned in the comprehensive plan, should be complemented by one more high-speed traffic street new drive from Kaunas - Vilnius highway, - laid along the planned Nordic street route, which would be linked with the Nemenčine road. The best would be if the street could be laid in 5-6 years (especially the section from the West highspeed street to a junction with Nemenčinè road).

6. The first priority in the central part of the city should be sustained laying of Kernave Bridge across the Neris river (along Giedraičiu street) at least to Ozo Street, better up to Baltupiu region. - Second priority - reconstruction of Geležinio vilko - Ukmergès street crossing and approach.

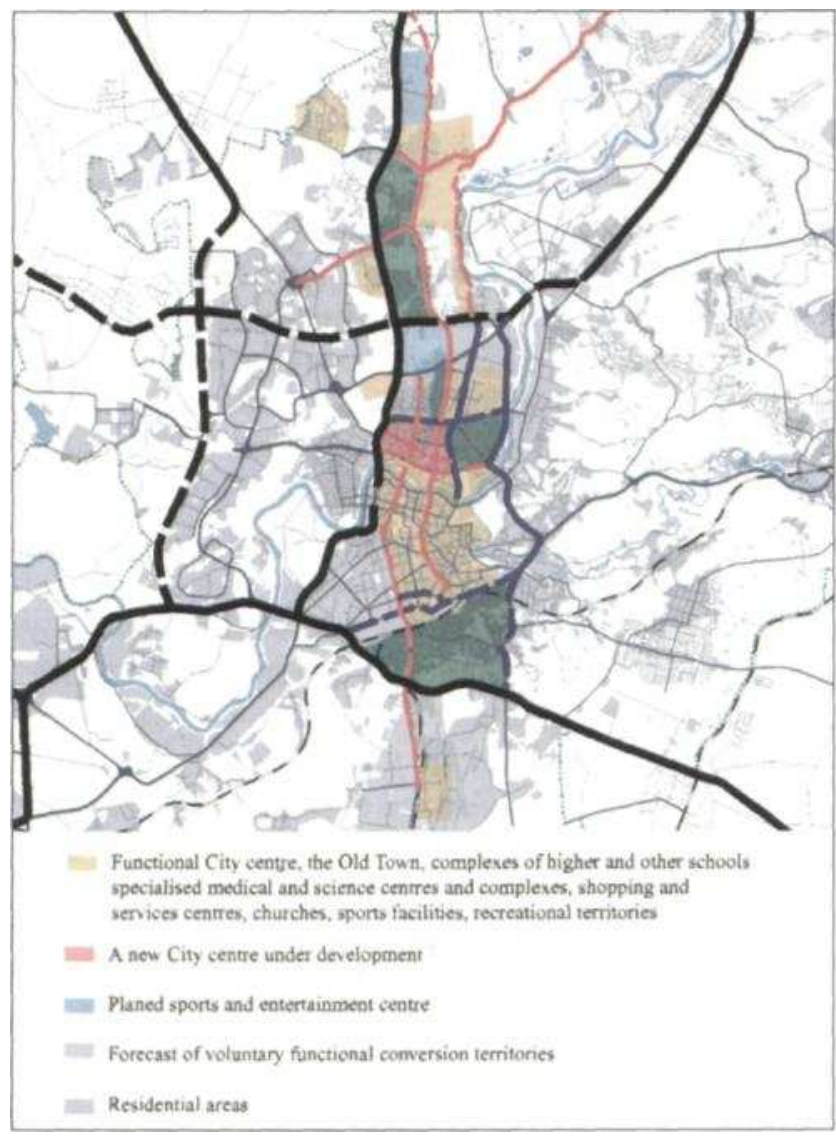

Fig 6. Functional axis of Vilnius and its transport services

7. The third priority should be a construction of duplicating Lazdynu bridge and streets. The main purpose is to shift the routes of the public passenger transportation. For the normal functioning of the street network and tracks would be necessary to lay two junctions - along Gerosios vilties and Paneriu - Vilkpèdès streets routes up to Lazdynu and Šiltnamiu streets. Which street should be laid at first should be decided after a detailed analyse. In addition, the concrete implementation terms should be co-ordinated with South high-speed street construction terms.

8. The forth priority - to join Zarasu and Paneriu streets.

9. The fifth priority - reconstruction of Rinktinès, Apkasu and Verkiu streets. The objective of the reconstruction - laying a street with sufficient conductance and possible to duplicate the Kalvariju Street. The concrete term of works should be connected to the modern tram lay in Kalvarijų Street.

10. For the real conceivable future it should be proposed a study a lines cross North - South and South and West. Construction of them and operation could go with the further expansion to 
cration could go with the further expansion to suburbs. The traffic regime - from modern to modern high-speed in the peripheral (urban region) zone.

11.The trolley-bus network should be kept and its formation should be completed. Thereto would be necessary to prolong contact net from Laisvès Ave along the Ateities street (across Baltupiu region) up to junction with net in Kalvarijų street

12.The project of tramline network and tracks should be presented in a context of total passenger transportation system as an integrated subsystem project.

13.Initiation of substantiation works for the computerised system of Vilnius central part traffic management (regulation) technical system and market analyse of that type of systems.

14. Preparation of the planned object implementation timetable plan with the objective to keep the transportation system viable and efficient in any urban life and development momentum.

\section{Literature}

1. Strategy Report. Metropolitan Region Berlin-Brandenburg. Gemeinsame Landesplanung Berlin-Brandenburg. Potsdam, 1999. 96 p.

2. Regional Development Plan for the County of Stockholm. Summary. The office of Regional Planning and Urban Transportation, 2000, p. 30.

3. Vilniaus vizija 2015. Vilniaus miesto savivaldybè, 1996. $50 \mathrm{p}$.

4. Vilniaus miesto bendrasis planas. Vilniaus miesto savivaldybe், 1999, 78 p.

5. Strategia rozwoju Gdyni. Urzond miasta, Gdynia, 1999.

7. Kvarda, W. Entwicklungschancen im grossraum Wien Bratislava. Medzinarodny seminar „Susedstvo'21", Slovenska technicka univerzita, Bratislava, 2000.

8. Juškevičius P. Miestų susisiekimo sistemų planavimas. V: Technika, 1995. 212 p.

9. Major trends characterizing. Human settlements development in the ECE region. UN. New York and Geneva, 1988. $80 \mathrm{p}$.

6. Guidelines on sustainable human settlements planning and management. UN, New York and Geneva, 1996. $64 \mathrm{p}$.

10. Vilniaus miesto 2002-2011 metų strateginis planas. Vilniaus miesto savivaldybè, S\{ „Vilniaus planas", Vš „Ekonominių tyrimų centras", UAB „Viešujų ryšių part neriai", 2002. 